\title{
Developing wellbeing at work: Emerging dilemmas
}

\author{
Pertti Laine · Risto Rinne
}

\begin{abstract}
Developing wellbeing at work is one of the most challenging tasks in contemporary society. As no single definition of wellbeing at work is commonly accepted as the most comprehensive and relevant, we introduce a discursive definition. We argue that wellbeing at work is associated with many contradicting dilemmas concerning both the development process and wellbeing at work itself. In the development processes of four organizations, analysed using data gathered in interviews with the key actors in the processes, seven such dilemmas of major importance for development are identified. The dilemma theory is helpful in charting the emerging dilemmas in developing work wellbeing and the theory contributes to the construction of better development processes.
\end{abstract}

Keywords: Wellbeing at work, dilemma management, development process

\section{Introduction}

The aim of this article is twofold. First, we will introduce our idea and definition of wellbeing at work (WW). It is necessary to demonstrate what the essence of the phenomenon WW is when discussing the challenges we face in enhancing it. Secondly, we argue that developing WW is a process where many decisions are made, many of them being unconscious and hidden. Those decisions are strongly associated with values, which in many cases are contradictory. Different values result in paradoxes and dilemmas: it is hard to choose between different contradictory alternatives. The issues raised are at the core of dilemma theory (Hampden-Turner, 1990; Hampden-Turner \& Trompenaars, 2000). Dilemma theory contributes to enhancing WW by making visible the many decisions and the value contradictions it involves. We apply dilemma theory in our research to better understand the value-based decision-making process in WW development.

Enhancing WW is strategic in nature. The business strategies of companies often rely on a resources-based view or theory (RBV, RBT) (e.g. Amit \& Schoemaker, 1993; Barney, 1991, 2001; Prahalad \& Hamel, 1990), which in principle also gives strategic importance to WW issues. However, in practice it seems that WW is often discussed one-dimensionally. Lack of a holistic view of WW makes us concentrate on problems of ill-being only; the costs of sick leave, for instance. We argue that having a more holistic view of WW and being more conscious about the nature of WW development as a decision-making process, with its value contradictions and dilemmas, would also make it easier for WW issues to gain strategic importance. This in turn is one of the major conditions for moving ahead in WW development.

The purpose of this article is to work on identifying the dilemmas we encounter in decision making in practice when executing WW development projects. First we will introduce a 'contemporary view' and definition of WW. Then the dilemma theory will be discussed in more detail. After that we introduce four WW development projects and examine what kind of dilemmas can be identified 
to challenge the implementation of plans to promote WW. Finally the results will be discussed and some ideas for further research will be presented.

\section{A contemporary idea of wellbeing at work}

\subsection{Our view of a definition of WW}

To form a holistic picture of WW we first introduce our analysis of WW as a concept. We differentiate between the subjective experience of WW and affecting and resulting factors (see Figure 1 below).

Figure 1: Different views related to a definition of WW

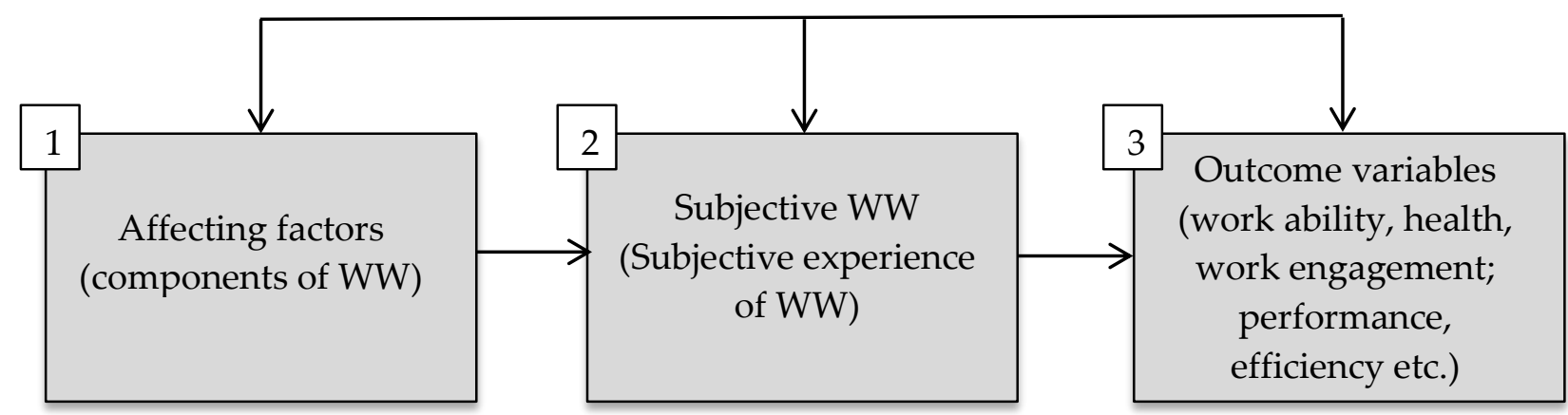

We see the different components of our conceptualization of WW to be tightly connected to each other. Experiences of health or high levels of performance, for instance, necessarily affect our subjective and general experience of WW. Some 'affecting factors' may have an impact on performance level without having any significant effect on the general experience of WW. The relations and connections are many. One major issue in our conceptualization is where to place work stress and other factors indicating ill-being - factors that often have been used as indicators of WW in general. We see each as a kind of mediating factor resulting from different things (e.g. heavy work load) and having an impact on subjective wellbeing. So we see them as 'affecting factors', to emphasize that the subjective experience of wellbeing should be seen as the general indicator of WW. So, stress-related factors are placed in the first box in Figure 1. In spite of the emerging difficulties of our classification we see that it gives us a practical base for discussing WW as a concept and we will use it in the following discussion.

\subsection{Affecting factors - components of WW}

We conducted a literature review of 14 key databases in different sciences for peer-reviewed articles on WW issues. We wanted to see how WW has been discussed and defined in scientific articles in relation to our classification in Figure 1. First, using the most common terms of WW ('wellbeing at work' OR 'work wellbeing' OR 'occupational wellbeing' OR 'employee wellbeing') we got 422 matches (duplications having been removed). More than 90 per cent of matches were from the year 2000 or later, which reveals the recent emergence of WW as a concept. Then, we analysed the abstract content of the material and rejected irrelevant articles, ending up with 316 articles. That material was then classified into seven categories of affecting factors formed by a discursive research of the Finnish peer-reviewed articles (Laine, 2013). The categories were also well suited for international data: 66 per cent of the articles could be properly classified in the given categories. However, looking at the total spread of the material it can also be seen that the search result is quite dispersed, which tells us that the concept of WW has not yet become 
properly established. Based on the literature we present a discursive classification of factors involved in forming the experience of WW ('affecting factors' in Figure 1 above) (see Table 1 below).

In Table 1 below we present only a few 'randomly picked' examples of the literature to show evidence for our discursive classification. The criteria for classifying our material in the discursive categories were not univocal: for instance, is workflow a work content issue or is it an individual and motivational factor? We were forced to choose based on our own subjective opinion which of the many possible criteria were the most dominant and which best described the article's content. However, as our target was simply to form a big picture, we believe that the discursive categories outlined reflect the research reality accurately enough for us to take these categories as a base for our 'discursive definition' of WW.

\subsection{Subjective WW and resulting factors}

Most contemporary definitions of WW seem to use subjective emotion or feeling as a general indicator of WW (box 2 in Figure 1). WW can be connected to the construct of subjective wellbeing (SWB), which refers to people's cognitive and affective evaluations of their lives (e.g. Diener, 2000). Also, the construct of affective wellbeing determines the presence of wellbeing in terms of different experiences, which in turn are determined by different emotional feelings such as arousal and pleasure (Warr, 1987a, 1987b). These views applied in defining WW move the focus from traditional stress theory and ill-being-based conceptualization to theories on wellbeing. We see this as a major paradigm shift. In this connection the construct of psychological wellbeing also arises (e.g. Ryff \& Keyes, 1995; Schmutte \& Ryff, 1997). Psychological wellbeing represents “a generalized feeling of happiness" (Schmutte \& Ryff, 1997, p. 551) and it can be reviewed dimensionally by its components of positive psychological functioning. These dimensions encompass a breadth of wellness that includes positive evaluations of oneself and one's past life (self-acceptance), a sense of continued growth and development as a person (personal growth), the belief that one's life is purposeful and meaningful (purpose in life), the possession of quality relations with others (positive relations with others), the capacity to manage effectively one's life and surrounding world (environmental mastery), and a sense of self-determination (autonomy) (Ryff \& Keyes, 1995). These dimensions can be viewed easily from the work perspective as well. To summarize this brief discussion on the subjectivity of WW we cite here the comment of Bridget Juniper (2011, p. 25): “The literature on this subject [defining employee wellbeing, EW] shows EW to be subjective and multidimensional. [...] EW is: that part of an employee's overall wellbeing that they perceive to be determined primarily by work and can be influenced by workplace interventions". We need the overall concept of WW to express the condition of the working life and to relate to the needs for its development. For operationalizing WW from the affective and subjective basis the long research tradition on wellbeing in general should be acknowledged.

In our literature review articles representing the 'resulting factors' (box 3 in Figure 1 above) also emerged. In our classification we had a category 'other emerged factors' for those issues we could not place in any of the seven categories in Table 1 below. Altogether 26 articles out of 106 were placed in the category describing the influences of WW. It seems that there is a growing interest in reviewing WW's influences on the performance and efficiency of the workforce and in seeing its development as an investment. 


\section{Table 1. Factors affecting the experience of WW: discourses}

\section{WW discourse: 'affecting factors'}

(1) Health issues and a health-promoting way of living. Healthy working environment; accidents and risks.

(2) Work/family roles; work/non-work interference: conflict or support, enrichment.

(3) Individual factors and personality.

(4) Working life uncertainties and threats (changes in the work context; threats of layoffs etc.).

(5) Work related factors (meaning and content of work, work strain, competence, etc.) Also work stress and research concerning different work contexts.

(6) Human relations and social factors at the workplace.

(7) Management; leadership style; personnel policy.

(1) - (7) total

(8) Other emerged factors (e.g. performance, efficiency, concept, methods, development projects).

\section{No. of articles References: Based on the literature review of peer-reviewed scientific articles and other} (\%) relevant literature (only some examples)

$58(18)$

Cotton \& Hart (2003); Janz, Champion, \& Strecher (2002); Nixon, Mazzola, Bauer, Kruger, \& Spector (2011); Pitt (2008); Prochaska, DiClemente, \& Norcross, (1992); Pronk \& Kottke (2009); Sparks, Faragher, \& Cooper (2001).

10 (3) Amstad, Meier, Fasel, Elfering, \& Semmer (2011); Bhave, Kramer, \& Glomb (2010); Dockery, Li, \& Kendall (2009); Geurts \& Demerouti (2003); Hamer, Kossek, Anger, Bodner, \& Zimmerman (2011); Huffman, Sanders, \& Culbertson, (2011); Livingston \& Judge (2008).

14 (4) Antonovsky (1993); Carmeli, Yitzhak-Halevy, \& Weisberg (2009); Chiaburu, Oh, Berry, \& Li, (2011); Le, Oh, Robbins, Ilies, Holland, \& Westrick (2011); Robbins, Allen, Casillas, Peterson, \& Le (2006); Vasilopoulos, Cucina, Dyomina, Morewitz, \& Reilly (2006); Vasilopoulos, Cucina, \& Hunter (2007); Zellars, Perrewe, \& Hochwarter (2000).

7 (2) $\quad$ Hellgren \& Sverke (2003); Hu \& Schaufeli (2011);_Kossek, Kalliath, \& Kalliath, (2012); Parzefall (2009); Quinlan (2007).

67 (21) Demerouti, Mostert, \& Bakker (2010); Maslach and Leiter (1997); Raediker, Janssen, Schomann, \& Nachreiner (2006); Rodriguez-Sanchez, Schaufeli, Salanova, Cifre, \& Sonnenschein (2011); Salanova, Bakker, \& Llorens (2006); Schaufeli, Salanova, Gonzales-Roma, \& Bakker (2002); Seligman \& Csikszentmihalyi (2000)

13 (4) Harrison (2013); Lozada, D'Adamo, \& Fuentes (2011); McGrath (2012); Welbourne, Gangadharan, \& Sariol (2014); many works of the classics on human relations at the workplace.

39 (12) Alimo-Metcalfe, Alban-Metcalfe, Bradley, Mariathasan, \& Samele (2008); Liu, Siu, \& Shi, (2008); McMurray, Pirola-Merlo, Sarros, \& Islam, (2010); Skakon, Nielsen, Borg, \& Guzman (2010) (systematic meta-analysis of 49 articles from 1980-2008).

108 (34) (Diverse and scattered material; no examples taken) 


\subsection{Summing up the discursive definition of WW}

In Figure 2 below we present an illustration which sums up the previously mentioned ideas on WW. We call this totality the 'discursive definition' because it is based on discursive approaches and ideas found in scientific articles.

Figure 2: Discursive definition of WW: (1) affecting factors, (2) subjective WW and (3) resulting factors

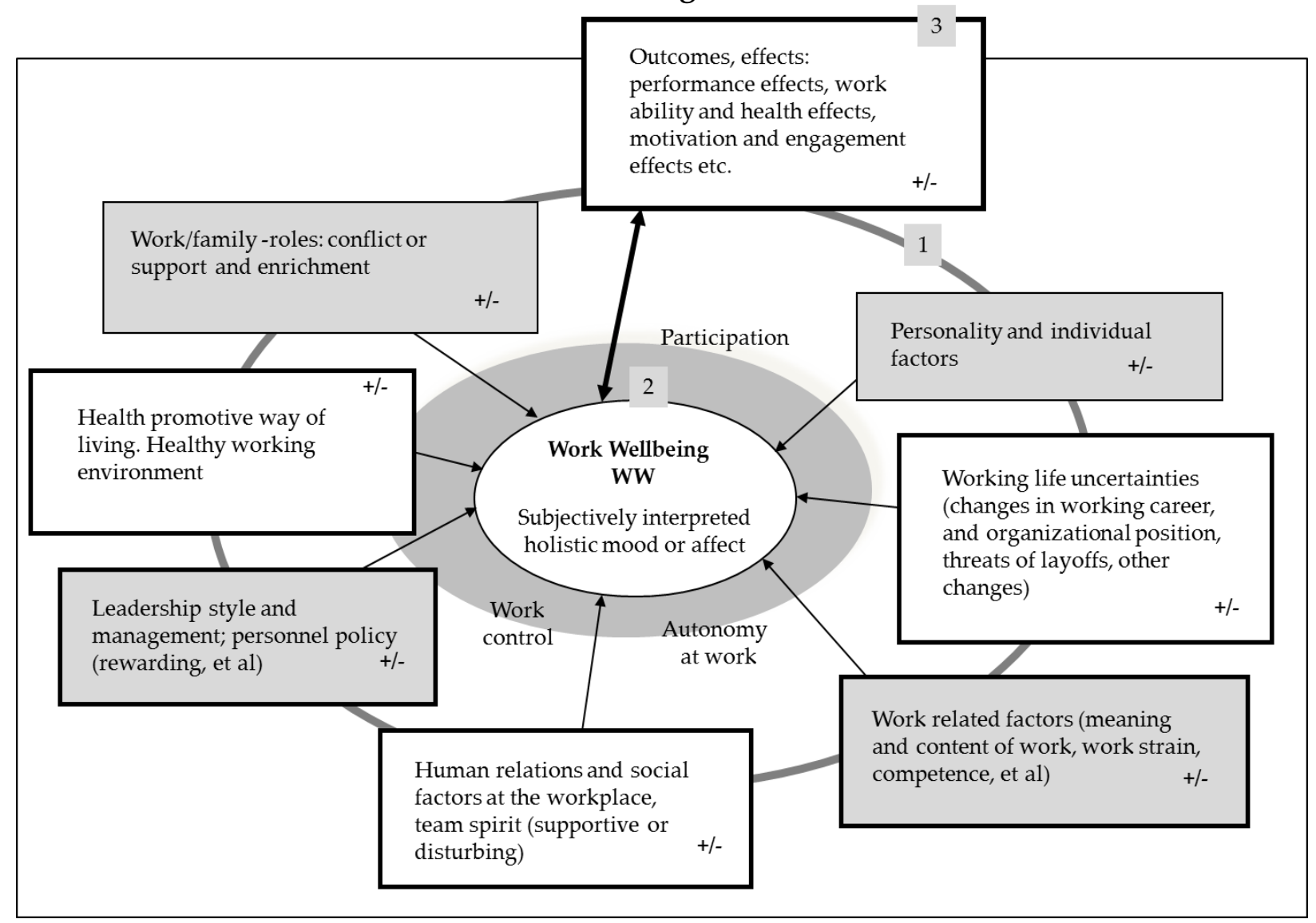

The illustration of WW also contains a dynamic element. Plus/minus symbols (+/-) in each of the boxes stand for a positive or negative effect on WW. For instance a work team (team spirit) can be strongly supportive of WW, but if some members are replaced or the personnel involved change, the effect can be disastrous overnight. Unexpected threats of layoffs can totally change employees' perceived security and turn uncertainty into the most dominating factor of their experienced WW.

Having a holistic view of WW makes its development very challenging and puts high demands on the process of development. Our view of WW requires processes featuring three essential qualities: (1) diagnosing the most essential things affecting people's subjective feeling about their WW at a given point in time; (2) a wide view on WW not excluding any potential means for enhancing it; and (3) considering and evaluating the outcomes from the perspective of all parties. These principles were applied in the projects of our four cases. One CEO who is cited later in this article states: "[investing in WW] doesn't mean these days for Nordic walking [refers to "refreshment days" organized by employer where some physical activities are exercised] [...] if that is the only way, we are walking in the swamp [expresses his view on the traditional way of taking care of WW]". Our conceptualization above introduces a more comprehensive and systemic perspective to the development of WW. 


\section{Dilemma theory - in search of the optimal mix}

Having now presented our view of WW we move to discuss the challenges involved in its development. We face contradictions in everyday decision making when different values cause incoherence in choosing between the options that constitute the decision. Those alternatives or choices associated with decision making can be called practical dilemmas. The opposite of 'pure dilemmas', which are insoluble, practical dilemmas can add value by a process that is called reconciliation. This idea is associated with eastern philosophies, which endeavour to find harmony and see contradictions to be an enriching power (Hampden-Turner, 1990; HampdenTurner \& Trompenaars, 2000).

To illustrate dilemmas and reconciliation between them, Hampden-Turner (1990) applied a matrix with $\mathrm{x}$ - and $\mathrm{y}$-axes representing the opposing values. The objective of the reconciliation is to reach the upper right corner of the matrix where synergy is gained. A compromise is placed in the middle of the matrix, representing a situation where nobody is happy and where no synergy is achieved (see Figure 3 below).

Figure 3: Opposing value dimensions and reconciliation process (adapted from HampdenTurner, 1990)

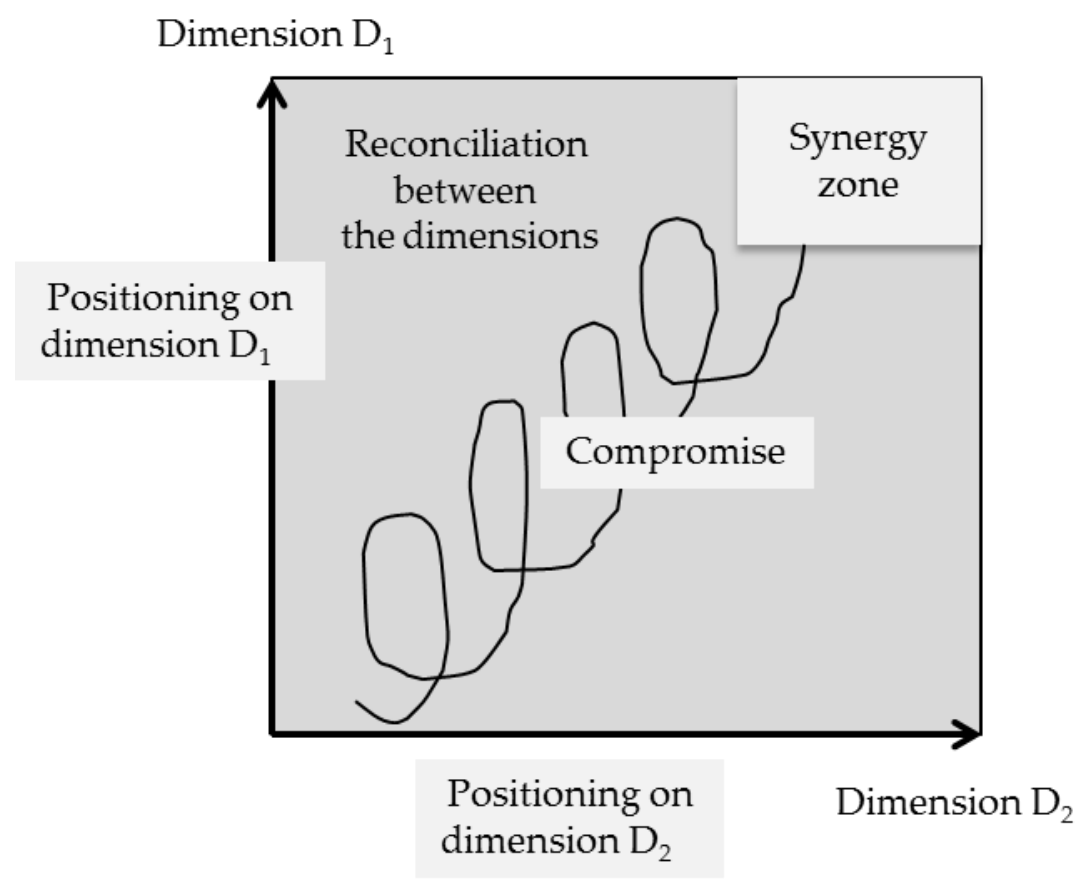

The reconciliation process is illustrated as a spiral, which stands for the continuous learning curve in search of balance and synthesis. We are continuously looking for better ways of performing and doing things and no solution is permanent. We applied the matrix differently by seeing the positioning on the $x$ - and $y$-axes as representing the optimal value or quality combination in the prevailing situation (see Figure 4 below).

For instance, given cost-effectiveness (time consumption) and engagement with development as opposing values, the positions reached in the reconciliation process stand for the optimal time invested in relation to the level of engagement and the involvement created. Typically, many of these relations may appear in the shape of a turned U-curve: 'too much of a good thing' (time in our case) may turn the implications to a negative direction (see e.g. Le et al. (2011)). 
Figure 4. Reconciliation for an optimum mix of opposing values (Laine \& Kuoppakangas, 2015)

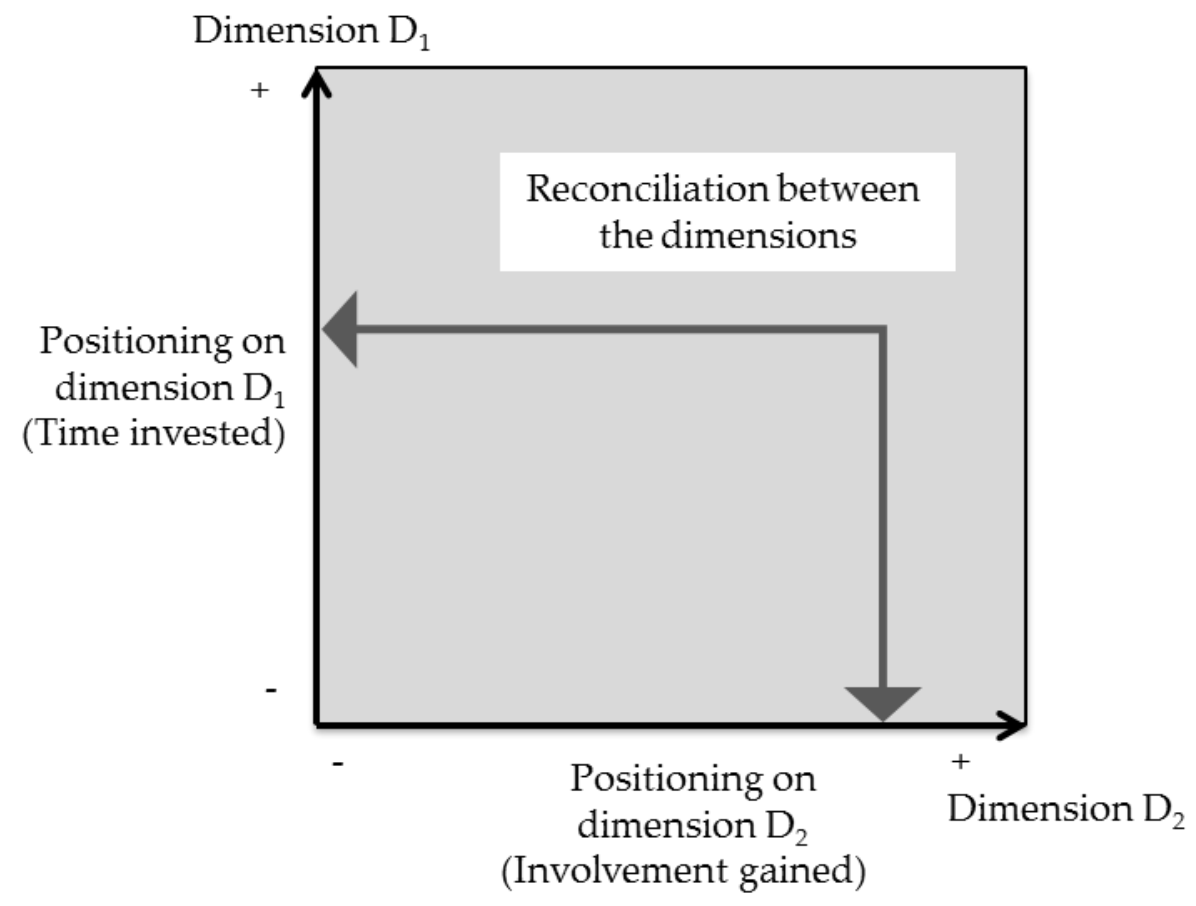

This description of reconciliation relates to 'rational-appearing' decision making. We are aware of two contradicting powers and reconcile them to reach the optimal decision. To go deeper into our application of the dilemma theory, we distinguish between conscious decision making and the dilemmas associated with it, and unconscious or hidden positioning in relation to dilemma continuums affecting the explicated decisions. The second type of dilemmas may contain prejudices or stereotypes, which might prove to be false after further consideration. According to this distinction we have explicit dilemmas based on rational-appearing consideration and implicit or hidden dilemmas affecting the former. When, later in this article, we concentrate on the empirical evidence, we interpret the positioning of the informants by how they express themselves in relation to the values under discussion. Positions estimated in this way are more related to hidden values than to explicated decision making.

Hampden-Turner's idea of reconciliation (1990) presumes that there is something to be reconciled; it presumes a dimensional look at the values. We are not making 'either/or' judgements but 'both/and', meaning that we are including 'some amount' of both qualities in our decision. The question is 'how much'; what is the optimal mix in the prevailing context? Our example of time invested to create engagement is a typical one. On the 'rational side' we may calculate that by making a certain extra investment in processing, we can generate a certain amount of engagement (bearing in mind the difficulties concerning the measurement of this relationship). On the 'hidden side' we may have the view that things don't need to be processed but that employees should be engaged; that's what they are paid for. Or we may see that processing things is extremely important to get employees engaged and understand what the change is all about. The prejudices we bring to the process will affect our final positioning.

To conclude, we list our perspectives of applying the dilemma theory:

1) Organizational decision making is based on values which in many cases are opposing or contradicting, creating dilemmas. Practical dilemmas can be solved and taken advantage of. 
2) Organizational decision making is dimensional by nature; in most cases we target the finding of a 'both/and' solution and value-adding harmony, by combining the values.

3) The process in which we search for harmony and the optimal mix of values searched is called the reconciliation process. It can be seen as a continuous learning process, which takes us to better decisions.

4) We distinguish between formal decision making and implicit positioning on value dimensions. In reviewing formal decision making it is important to be able to identify the hidden positioning.

5) From a practical point of view, the reconciliation process should be seen as threedimensional, with factors other than the values under consideration affecting decision making. Those 'other factors' can also be used as excuses to hide our 'real positioning' on the value dimensions.

\section{Aims and method}

The objective of this paper is to identify the core dilemmas emerging when implementing four WW development projects. The research question is formulated as follows: what kinds of dilemmas and value positioning can be identified concerning the development of work wellbeing (WW)?

We applied a multiple case-study approach (see e.g. Yin (2003)) as we reviewed the experiences and views of 18 informants in four case organizations in 2008. The 18 people were not randomly picked to represent the organization; they were the actual main actors for making decisions, or influential in some other respect concerning their development project. As each development project was based on mutual cooperation, the representatives also had an important role in implementing the projects. The informants and their organizations are introduced in Table 2 below. We shall not introduce the organizations in more detail (we promised not to identify the organizations in our reports) but we think that the general information of the work processes given in Table 2 below is enough for the research purposes here. We shall come back to the limitations of the research material and the case organizations later in the discussion.

All the projects were academically supported and 50 per cent publicly financed, and proper research plans and reporting were required. The projects aimed, first, to identify the state of WW in the case organizations (a standardized questionnaire, QPSNordic, was used for mapping the situation) and secondly, to innovate concrete means for enhancing WW. The overall goal was to engage the key persons (the top management and the trustees) and the whole personnel in the common development of WW in order that they would see its importance. The projects were conducted in the organizations by applying principles of Participatory Action Research (PAR) where learning in the process played a big role (Elden \& Levin, 1991). The interviews reported here constituted the first phase of the interventions, in which the informants' position on WW issues was reviewed. 
Table 2. The informants and their organizations

\begin{tabular}{|c|c|c|c|}
\hline $\begin{array}{l}\text { Target organization/ } \\
\text { informants }\end{array}$ & $\begin{array}{l}\text { Industry } \\
\text { (nature of the work } \\
\text { process) }\end{array}$ & Number of personnel & $\begin{array}{l}\text { WW project } \\
\text { (Supervisor + number } \\
\text { of team members) }\end{array}$ \\
\hline $\begin{array}{l}\text { Enterprise } 1 \\
\text { (ProTec 1) } \\
\text { - mill manager } \\
\text { - chief trustee of employees } \\
\text { - supervisor } \\
\text { - health and safety rep } \\
\text { - production manager } \\
\text { Total } 5\end{array}$ & $\begin{array}{l}\text { Process industry } \\
\text { (process control). }\end{array}$ & $\begin{array}{l}\text { Corporation } \\
1332 . \\
\text { Factory } \\
196 .\end{array}$ & $\begin{array}{l}1 \text { shift } \\
1+14\end{array}$ \\
\hline $\begin{array}{l}\text { Enterprise } 2 \\
\text { (ProTec 2) } \\
\text { - mill manager } \\
\text { - chief trustee of employees } \\
\text { - production manager } \\
\text { - supervisor } \\
\text { - health and safety rep } \\
\text { Total } 5\end{array}$ & $\begin{array}{l}\text { Process industry } \\
\text { (process control). }\end{array}$ & $\begin{array}{l}\text { Corporation } \\
1800 . \\
\text { Factory } \\
160 .\end{array}$ & $\begin{array}{l}1 \text { shift } \\
1+16\end{array}$ \\
\hline $\begin{array}{l}\text { Enterprise } 3 \\
\text { (MetTec 1) } \\
\text { - CEO } \\
\text { - chief trustee of employees } \\
\text { - production manager } \\
\text { - supervisor } \\
\text { - health and safety rep } \\
\text { Total } 5\end{array}$ & $\begin{array}{l}\text { Metal industry } \\
\text { (shift work) }\end{array}$ & $\begin{array}{l}\text { Corporation } \\
1085 . \\
\text { Factory } \\
800 .\end{array}$ & $\begin{array}{l}2 \text { shifts } \\
1+17 \\
1+16\end{array}$ \\
\hline $\begin{array}{l}\text { City } 1 \\
\text { (Nursing Home 1) } \\
\text { - director of social security } \\
\text { - director of nursing home } \\
\text { - chief trustee of employees } \\
\text { Total } 3\end{array}$ & $\begin{array}{l}\text { Public administration } \\
\text { (elderly care). }\end{array}$ & $\begin{array}{l}\text { City admin. personnel } \\
1699 .\end{array}$ & $\begin{array}{l}\text { Nursing home } \\
\text { personnel } \\
2+30\end{array}$ \\
\hline $\begin{array}{l}\text { Grand total } \\
18\end{array}$ & $\begin{array}{l}\text { Industry } 15, \\
\text { elderly care } 3 .\end{array}$ & $\begin{array}{l}\text { Time of the interviews } \\
15 \mathrm{~h} 47 \mathrm{~min} .\end{array}$ & $\begin{array}{l}\text { Interview average/ } \\
\text { informant } \\
53 \mathrm{~min} .\end{array}$ \\
\hline
\end{tabular}

In order to collect the data we applied the Semi-Structured Depth Interview (SSDI) method, which covers many different interview strategies from completely structured to completely unstructured interviews (Wengraf, 2001). In our case the interviewer had some thematic questions planned in advance. These thematic interviews lasted, on average, a little less than one hour. The interviews began with a short introduction of the content of the project, and the thematic areas of the interview were briefly described. General questions about the business were presented as well at the beginning (adjusted for the interests and knowledge of the interviewees) to start the interaction using the most familiar issues. The interviews were audio-recorded and 
the main parts were transcribed (some 200 pages of text in Finnish) and relevant quotations were translated into English. The analysis proceeded in several phases and it was conducted by searching for the dilemmas based on WW conceptualization. So the analysis was partly guided by the presented theory of WW, in which dilemmas are for the most part hidden, but it was also oriented to allow ideas from the interview situation to emerge. This kind of reasoning and approach can be called 'abductive', and the analysis applied can be termed 'framework analysis' (Lacey \& Luff, 2001). After a couple of readings the main thematic areas - dilemmas - were identified and the next readings were focused on finding more evidence, illuminating the dilemmas and reviewing the positioning on the dilemma dimensions. The action research process also accumulated material on discovered dilemmas and positions. The processes of the four cases contained 20 workshops altogether and the workshop discussions were documented and analysed from a dilemma point of view. We shall come back to the restrictions of our multiple-case study and analyses applied in the discussion.

\section{Results: the emerging dilemmas in developing WW}

The core dilemmas presumed by the literature and which emerged and were 'tested' in the interviews are recapitulated in the following list. Many other dilemmas could be identified as well, but we chose the core and general level dilemmas, which can, according to our experience of many processes, be easily found in other similar situations.

1) Adapting the personnel to work demands vs. developing the work and work environment

2) Responsibility of individual vs. responsibility of employer

3) Source of exhaustion: working life vs. private life

4) WW as a cost factor vs. WW as an investment / WW as earnings-generating factor

5) Reactive vs. proactive development of WW

6) Innovative renewing vs. unwillingness to change, and

7) Development vs. production priority

In our dilemma concept, as stated previously, the dilemmas are not necessarily associated with concrete decision making between concrete options; they are more underlying positions that may have an effect on decision making in a more implicit way. Dilemmas here are more opposing and contradicting positions that emerge as reactions in certain situations where change is occurring. Before going more deeply into the specific dilemmas and positions, one very important general level observation of the interviews was made:

not one of the informants raised WW as a strategic level issue and as a strategic success factor important for the long-term success of the organization. This can be seen as the dilemma of all dilemmas in that this hidden position affects most of their subsequent choices (see Hampden-Turner (1990), p. 157).

Without shared strategic importance, the development of WW will probably encounter serious problems. Another general level observation was that the positioning of the informants on the dilemma dimensions was not strongly contradictory in nature. In spite of them having different values and organizational positions, their views were taken in a comprehensive and holistic way. That is a good sign from a cooperative development point of view. We shall next move to discuss the emerged dilemmas and the identified positioning in regard to the dilemmas. 
5.1 Dilemma 1: Adapting the personnel to work demands vs. developing the work and work environment Not one of the informants saw this contradiction or question to be a dilemma as we define it; not one of the representatives of the employer said, for instance, that 'we should improve the working conditions of the employees to create better WW' but instead emphasized more what the workers should do. Also, the perspective of listening to people is included in this dilemma; if employees are not heard, they are probably more adapted to the demands of production according to the views of the decision makers. So signals indicating that the work strain is too heavy, without having the possibility to control it, tell us about the 'personnel adaptive' value position of the decision-makers.

[What is expected...?] '[...] that employees would come to work with pleasure and would follow the given orders and instructions [...] that they were really interested in what they are doing, by that we shall get better results [...]'. (Production manager, ProTec 1).

'[...] especially the young employees see [...] that you have no chances to have an impact on anything [...] older workers on the other hand are only waiting to get rid of this rat race by the help of some system [refers to the pension system] [...]'. (Chief trustee of employees, ProTec 2).

[Does employer listen...?] 'I must say that not always or is not sufficiently interested in what we are saying $[. .$.$] quite often feels like they turn a deaf ear [...]'. (Chief trustee of$ employees, ProTec 2).

Statements indicating this dilemma were many and they represented mainly the 'personnel adaptive' value position. This adaptive strategy seems to have been the mainstream strategy executed in Finnish working life (Mäkitalo, 2005).

\subsection{Dilemma 2: Responsibility of the individual vs. responsibility of the employer}

Based on the interviews, the responsibility of WW was mostly seen to belong to all the parties, not to one actor only. However, different kinds of responsibilities were identified where the responsibility of one actor was emphasized. Especially, the responsibility of living a healthpromoting lifestyle is seen to belong to the individual and the role and the chances of the employer in this respect are seen as limited. On the other hand, issues which are related to resources (e.g. investments in equipment or the number of personnel) are self-evidently seen as the responsibilities of the employer.

'... it is not an employee alone [...] but an employee should have own motivation and will to keep fit and to change his/her lifestyle healthier [...] if you are in good shape you manage better at the work place but if you have bad problems you don't have enough energy to exercise [considering this paradox]'. (Chief trustee of employees, ProTec 1).

[Employer responsibility...?] 'Speaking about human beings I mainly want moderateness from the employer and listening of conscience [opinion of the responsibility of the employer]'. (Chief trustee of employees, ProTec 2).

'[...] but however, I would see the management [...] it is their responsibility to give the impulse [for developing WW]'. (Chief trustee of employees, MetTec 1).

[Employer responsibility...?] '[...] it is absolutely this adducing of the question of resourcing $[\ldots]$ very strongly, there seems to a strong desire for it $[\ldots]^{\prime}$. (Director of nursing home, Nursing Home 1). 
As taking responsibility for WW was mostly seen as even-handed and covering all parties, but also as being dependent on the kind of responsibility we are talking about, we should be more specific in setting our questions concerning the different responsibilities. In this connection the role and responsibility of a certain specialist function (i.e. medical or HR) vs. the responsibility of the line organization should also be discussed.

\subsection{Dilemma 3: Source of exhaustion: working life vs. private life}

The direction of WW-threatening factors ranges from work to employees' private lives (Hakanen, 2005). However, in the interview data statements supporting both views could be found. Also 'modern' views, which see working life and private life as being totally integrated, were presented. The teams at the workplaces involved seemed to have a remarkable role to play in supporting their members both in work and private life problems.

'This working society is very important in that it gives social support if something bad happens at home [...] I at least think that it will help if you have somebody at the work place to share the difficulties [...] a human being is the same for 24 hours.' (Mill manager, ProTec 2).

In managerial practice, the role of the supervisor in taking care of team members' $\mathrm{WW}$ has been emphasized. This has led some informants to see challenges concerning the intimacy of private life.

'It is good for the employer representative in his/her leadership to know something about the private life [of his/her team member] also, in a way to better manage the subordinate. But it is a bit difficult because some of these work wellbeing things are connected to private life.' (Production manager, ProTec 2).

In our research data, 'black and white' positions were lacking and most of the informants saw the mutually reinforcing meaning of working and private life.

\subsection{Dilemma 4: WW as a cost factor vs. WW as an investment / WW as an earnings-generating factor}

The next dilemma identified is related to seeing WW as a cost factor vs. also seeing possibilities to gain positive outcomes by developing WW. This refers to seeing investing in WW as having potential for increasing future earnings. None of the informants was positioned to see the costs only, with no positives involved in developing WW; however, the difficulty of identifying the benefits was emphasized. The more concrete the WW issue is, the easier it is to see it as an investment.

'It [seeing WW development as an investment] is a difficult question always, how much in an economically tight situation are we willing to invest in things like that [WW] [...] then we should see the things in long run [...] its value [...] of course other priorities will appear that will rise on a higher level [...]'. (Mill manager, ProTec 1).

[conversation on work accidents, following more than 400 working days with no accidents] '[...] so it is easier for the employer to invest in physical work safety for no accidents than in mental work safety things [... $]^{\prime}$. (Chief trustee of employees, ProTec 1).

Seeing the development of WW as a cost-generating 'sacrifice' is not promising from an investment point of view. It is even harder when the payback remains ambiguous.

'[...] was it two years ago when a whole day was sacrificed [...] there were things like work safety [...] our doctor told about a healthy style of living as well as mental wellbeing. 
It is hard to measure [...] [means pay back] [...] it is easy to measure the costs [...]'. (Mill manager, ProTec 2).

There were also points made concerning seeing investments in personnel as beneficial and earnings-generating, but a question of what constitutes real WW investment arises.

'[...] in principle I believe that investing in personnel pays back, but it doesn't mean these days for Nordic walking [refers to "refreshment days" organized by employer where some physical activities are exercised] [...] if that is the only way, we are walking in the swamp [expresses his view on traditional way of taking care of WW].' (CEO, MetTec 1).

'Perhaps you could also see [...] all system changes, building up a rewarding system, it is in a way investment in wellbeing by which the personnel is made engaged [...] making the shift schedule [...] they are not hard investments but [...]' (Production manager, MetTec 1).

When discussing the benefits of improved WW, the significance of the cost of sick leave emerged. People were very well aware of the average absence rate of five per cent and compared their rate to that. In our research data, the question of these costs dominated the WW discussion and in many cases WW was seen as being the same as job satisfaction.

'Ok, it [WW] is a cost [...] there come the sick leaves, they who are satisfied here, their threshold for taking sick leave is much higher than those who are dissatisfied.' (Production manager, ProTec 2).

\subsection{Dilemma 5: Reactive vs. proactive development of WW}

WW development has been criticized for being reactive. Observations based on interviews support this impression.

'I think that we are alert and follow these things [WW] and see case by case if we have some role in this [...] not just to let things be but to react [refers to a case when somebody left the company and the reasons why should be found out]'. (Mill manager, ProTec 2).

'Of course things like training, investment in equipment, shortages are being reacted to both in machines and personnel [...]'. (Chief trustee of employees, MetTec 1).

'Quite often we react only when we have a problem, only then we are awakened suddenly [...]'. (Chief trustee of employees, MetTec 1 ).

\subsection{Dilemma 6: Innovative renewing vs. unwillingness to change}

Adapting a wide conceptualization of WW has shifted the focus of development towards renewing working life, and therefore towards an emphasis on the innovative development of work processes (Laine, 2013). Striving for innovative changes also creates dilemma situations when the psychological costs of change are too large. This dilemma was easy to identify in the interviews, but also emerged when we conducted work seminars, which were also targeted towards discovering innovative work procedures.

[How do you see developing the work?] 'It is a good thing [...] and even if you want your work to be many-sided you are not willing to move when the opportunity is arranged [...] even today we had a case where the people in logistics would have a possibility to move to production, people were not interested.' (Production manager, ProTec 1).

'When I think of the work [in the metal industry factory] and see how monotonous it is, I would think that it is a risk for the WW of the employees [...] but there is surprisingly big amount of people who like this and feel unsure to take a step of changing the job.' (CEO, MetTec 1). 
This dilemma is the eternal one referred to in many studies, but it is worth rethinking. We should be able to create new means to support and motivate people in regard to change.

\subsection{Dilemma 7: Development vs. production priority}

In an industrial context, formulating the dilemma like this is a little provocative: of course production should be the priority. On the other hand, if development never takes place and production is always prioritized, the organization is sure to get into trouble in the long run. It is also a question of energy. If everyday production consumes all the energy of the employees, there is no room for development.

'[...] as today there is a need all the time to develop all the sectors it doesn't leave much room for development, if in a way your basic work gets all the energy' (Chief trustee of employees, MetTec 1).

\section{Discussion}

Work wellbeing, WW, is undoubtedly one of most challenging targets for change in contemporary working life, especially as there is no commonly accepted and shared definition of WW. Our conceptualization of WW highlights many attributes that can be connected to what we called a modern idea on WW. This wide, holistic and integrated 'discursive definition', based on discourses of WW identified in the Finnish material and supported by international findings, is a step in formulating frameworks for discussion on WW. In search of dilemmas affecting the development of WW, it is easy to notice that the concept of WW itself contains many contradictory features and elements. Combining all the ingredients of WW to form a 'harmonic mix' involves bringing together contradictory elements emerging from the different needs of individuals, families and working life. Most of these elements compete for our scarce resources, time and energy, forming practical dilemmas or paradoxes.

Dilemma theory as applied here highlights the contradictory value-based nature of working life decision making as well as the principle of dimensionality when positioning ourselves in relation to the elements of the decision. Also, the idea of reconciliation to describe the process where value positions are sought is useful in reviewing decision making. Our focus was on things affecting formal decision making in a development context, so we were more interested in hidden or implicit positioning in relation to the values. Considering the WW developmentspecific values by casting them in the form of dilemmas was well suited for pointing out the essentials of the hidden values.

Our research material was taken from interviews conducted in four development projects on WW. Three of the cases were industrial and one was in elderly care. As we had chosen a multiplecase-study approach, the case industries did not represent any particular part of working life but acted as fields for gaining concrete examples. As three of the cases were industrial and only one in the service industry, no comparisons were made between the industries. Also the interviewees were taken more as individual actors in the process than representatives of their personnel group, so no comparisons were made here either. This kind of qualitative case-study approach has many uncertainties but also has the potential to create a deeper understanding of complicated organizational phenomena (e.g. Lee, Collier, \& Cullen, 2007).

Based on the empirical data, seven dilemmas were identified. When considered in relation to the discursive conceptualization of WW, these dilemmas have also been found in general discussion and their existence was also supported by discussions of the referred projects in the workshops. As the emerging dilemmas were so numerous, we concentrated on charting the field 
of WW development and demonstrating the contribution of the use of dilemma theory. So within the framework of this paper, there is no room for further comment on the dilemmas that emerged.

\section{Conclusions}

To conclude, the following points can be made:

- The concept of work wellbeing (WW) is so young and still so scientifically undefined that meta-research on the concept would be expected; however, discursive definition of WW may offer some baselines for proceeding

- Dilemma theory, and its principles as contradicting value-based decision making, the idea of dimensionality with opposing ends or extremes and the search for synergy and harmony between extremes using a reconciliation process, are especially well suited to the development of an issue like WW

- The distinction between formal decision making and implicit positioning on value dimensions is important in understanding the challenges of the development of WW

- In principle, contradicting values are very likely to emerge in developing WW. In our case the positioning of the informants on the dilemma dimensions was not strongly contradictory in nature. However, this lack of potential conflict about WW is not enough to boost development - it should be changed into a more active mood of helping the progress of WW.

As this article concentrated on charting the field of developing WW, empirical research on the dilemmas of WW development is needed as well as research concentrating on each of the emerging dilemmas in more detail.

\section{Authors}

Pertti Laine

University of Turku

pertti.laine@utu.fi

Risto Rinne

University of Turku

Publishing Timeline

Received 1 August 2014

Accepted 23 March 2015

Published 21 June 2015

\section{References}

Alimo-Metcalfe, B., Alban-Metcalfe, J., Bradley, M., Mariathasan, J., \& Samele, C. (2008).The impact of engaging leadership on performance, attitudes to work and wellbeing at work. Journal of Health Organization and Management, 22(6), 586-598. http://dx.doi.org/10.1108/14777260810916560

Amit, R., \& Schoemaker, P. (1993). Strategic assets and organizational rent. Strategic Management Journal, 14(1), 33-46. http://dx.doi.org/10.1002/smj.4250140105

Amstad, F., Meier, L., Fasel, U., Elfering, A., \& Semmer, N. (2011). A meta-analysis of work-family conflict and various outcomes with a special emphasis on cross-domain versus matching-domain relations. Journal of Occupational Health Psychology, 16(2), 151-169. http://dx.doi.org/10.1037/a0022170

Antonovsky, A. (1993). The structure and properties of Sense of Coherence Scale. Social Science and Medicine, 36(6), 725-733. http://dx.doi.org/10.1016/0277-9536(93)90033-Z 
Barney, J. B. (1991). Firm resources and sustained competitive advantage. Journal of Management, 17(1), 99-120. http://dx.doi.org/10.1177/014920639101700108

Barney, J. B. (2001). Gaining and sustaining competitive advantage. Upper Saddle River, NJ: Prentice-Hall.

Bhave, D. P., Kramer, A., \& Glomb, T. M. (2010). Work-family conflict in work groups: Social information processing, support, and demographic dissimilarity. Journal of Applied Psychology, 95(1), 145-158. http://dx.doi.org/10.1037/a0017885

Carmeli, A., Yitzhak-Halevy, M., \& Weisberg, J. (2009). The relationship between emotional intelligence and psychological wellbeing. Journal of Managerial Psychology, 24(1), 66-78.

http://dx.doi.org/10.1108/02683940910922546

Chiaburu, D. S., Oh, I-S., Berry, C. M., \& Li, N. (2011). The Five-Factor Model of personality traits and organizational citizenship behaviors: A meta-analysis. Journal of Applied Psychology, 96(6), 1140-1166. http://dx.doi.org/10.1037/a0024004

Cotton, P., \& Hart, P. M. (2003). Occupational wellbeing and performance: A review of organisational health research. Australian Psychologist, 38(2), 118-127. http://dx.doi.org/10.1080/00050060310001707117

Demerouti, E., Mostert, K., \& Bakker, A. (2010). Burnout and work engagement: A thorough investigation of the independency of both constructs. Journal of Occupational Health Psychology, 15(3), 209-222. http://dx.doi.org/10.1037/a0019408

Diener, E. (2000). Subjective well-being: The science of happiness and a proposal for a national index. American Psychologist, 55(1), 34-43. http://dx.doi.org/10.1037//0003-066X.55.1.34

Dockery, A., Li, J., \& Kendall, G. (2009). Parents' work patterns and adolescent mental health. Social science $\mathcal{E}$ medicine, 68(4), 689-698. http://dx.doi.org/10.1016/j.socscimed.2008.10.005

Elden, M., \& Levin, M. (1991). Co-generative learning: Bringing participation to action research. Newbury Park: Sage.

Geurts, S., \& Demerouti E. (2003). Work/non-work interface: A review of theories and findings. In M. Schabracq, J. Winnubst \& C. Cooper (eds.), The handbook of work and health psychology (pp. 279-312). Europe: John Wiley \& Sons.

Hakanen, J. (2005). Työuupumuksesta työn imuun: työhyvinvointitutkimuksen ytimessä ja reunaalueilla. [From burn-out to engagement: In the core of and on the fringes of work-related well-being research. English abstract] Työ ja ihminen tutkimus-raportti 27. Helsinki: Työterveyslaitos.

Hamer, L., Kossek, E., Anger, W. K., Bodner, T., \& Zimmerman, K. L. (2011). Clarifying work-family intervention processes: The roles of work-family conflict and family-supportive supervisor behaviors. Journal of Applied Psychology, 96(1), 134-150. http://dx.doi.org/10.1037/a0020927

Hampden-Turner, C. (1990). Charting the corporate mind: From dilemma to strategy. Oxford, UK: Blackwell.

Hampden-Turner, C., \& Trompenaars, F. (2000). Building cross-cultural competence: How to create wealth from conflicting values. New York: John Wiley \& Sons.

Harrison, W. (2013). Working together. Occupational Health, 5(1), 18-19.

Hellgren, J., \& Sverke, M. (2003). Does job insecurity lead to impaired well-being or vice versa? Estimation of cross-lagged effects using latent variable modeling. Journal of Organizational Behavior, 24(2), 215-236. http://dx.doi.org/10.1002/job.184

$\mathrm{Hu}, \mathrm{Q}$., \& Schaufeli, W. B. (2011). Job insecurity and remuneration in Chinese family-owned business workers. Career Development International, 16(1), 6-19. http://dx.doi.org/10.1108/13620431111107784

Huffman, A. H., Sanders, A. M., \& Culbertson, S. S. (2011). Work-family research has a public relations problem: Moving from organizational nicety to necessity. Industrial and Organizational Psychology: Perspectives on Science and Practice, 4(3), 410-413. http://dx.doi.org/10.1111/j.1754-9434.2011.01363.x

Janz, N. K., Champion, V. L., \& Strecher, V. J. (2002). The Health Belief Model. In K. Glanz, B. K. Rimer, \& F. M. Lewis (eds.), Health behavior and health education: Theory, research and practice (pp. 45-66). San Francisco, CA: Jossey-Bass.

Juniper, B. (2011). Defining employee wellbeing. Occupational Health, 63(10), 25.

Kossek, E. E., Kalliath, T., \& Kalliath, P. (2012). Achieving employee wellbeing in a changing work environment: An expert commentary on current scholarship. International Journal of Manpower, 33(7), 738-753. http://dx.doi.org/10.1108/01437721211268294 
Lacey, A., \& Luff, D. (2001). Qualitative data analysis. Trent Focus Group. http://research.familymed.ubc.ca/files/2012/03/Trent Universtiy Qualitative Analysis7800.pdf

Laine, P. (2013). Developing wellbeing at work. In search of a good development process. (English Abstract) Doctoral Dissertation, Department of Education in the University of Turku, Turku.

Laine, P., \& Kuoppakangas, P. (2015). A reconceptualization of change strategy - one application of dilemma theory. Journal of Change Management. (Forthcoming.)

Le, H., Oh, I-S., Robbins, S., Ilies, R., Holland, E., \& Westrick, P. (2011). Too much of a good thing: Curvilinear relationships between personality traits and job performance. Journal of Applied Psychology, 96(1), 113-133. http://dx.doi.org/10.1037/a0021016

Lee, B., Collier, P. M., \& Cullen, J. (2007). Reflection on the use of case studies in accounting, management and organizational disciplines. Qualitative research in Organizations and Management: An International Journal, 2(3), 169-178. http://dx.doi.org/10.1108/17465640710835337

Liu, J., Siu, O., \& Shi, K. (2008). Transformational leadership and employee wellbeing: An examination of the mediating role of self-efficacy and trust in the leader. International Journal of Psychology, 43(3-4), 233.

Livingston, B. A., \& Judge, T.A. (2008). Emotional responses to work-family conflict: An examination of gender role orientation among working men and women. Journal of Applied Psychology, 93(1), 207216. http://dx.doi.org/10.1037/0021-9010.93.1.207

Lozada, M., D'Adamo, P., \& Fuentes, M. A. (2011). Beneficial effects of human altruism. Journal of Theoretical Biology, 289, 12-16. http://dx.doi.org/10.1016/j.jtbi.2011.08.016

McGrath, D. L. (2012). Interpersonal contact at work: Consequences for wellbeing. International Journal of Health, Wellness \& Society, 2(1), 33-47.

McMurray, A. J., Pirola-Merlo, A., Sarros, J. C., \& Islam, M. M. (2010). Leadership, climate, psychological capital, commitment, and wellbeing in a non-profit organization. Leadership $\mathcal{E}$ Organization Development Journal, 31(5), 436-457. http://dx.doi.org/10.1108/01437731011056452

Mäkitalo, J. (2005). Mitä on työhön liittyvä hyvinvointi. [What is work-related well-being. Text only in Finnish] In E. Paso, J. Mäkitalo \& J. Palonen, J. (eds.), Viimeinen tykykirja?. Merikosken kuntoutus- ja tutkimuskeskus ja Eläkevakuutusyhtiö Tapiola. Kolmas painos. Art-Print.

Maslach, C., \& Leiter, M. P. (1997). The truth about burnout: How organizations cause personal stress and what to do about it. San Francisco, CA: Jossey-Bass.

Nixon, A., Mazzola, J., Bauer, J., Kruger, J. R., \& Spector, P. (2011). Can work make you sick? A metaanalysis of the relationships between job stressors and physical symptoms. Work and Stress, 25(1), 122. http://dx.doi.org/10.1080/02678373.2011.569175

Parzefall, M-R. (2009). Irtisanominen kriisinä psykologisen sopimuksen näkökulmasta. [Layoff as a crisis in the perspective of psychological contract. The text only in Finnish.] Teoksessa H. Seeck (toim.), Kriisit ja työyhteisöt - kriisijohtaminen työyhteisöjen tukena. Työ ja ihminen Tutkimusraportti 37. Helsinki: Työterveyslaitos.

Pitt, M. (2008). Health and safety and health and wellbeing. Journal of Retail \& Leisure Property, 7(4), 263264. http://dx.doi.org/10.1057/rlp.2008.24

Prahalad, C. K., \& Hamel, G. (1990). The core competence of the corporation. Harvard Business Review, 68(3), 79-91.

Prochaska, J., DiClemente, C., \& Norcross, J. (1992). In search of how people change: Applications to Addictive Behaviours. American Psychologist, 47(9), 1102-1114. http://dx.doi.org/10.1037/0003066X.47.9.1102

Pronk, N. P., \& Kottke, T. E. (2009). Physical activity promotion as a strategic corporate priority to improve worker health and business performance. Preventive medicine, 49(4), 316-321. http://dx.doi.org/10.1016/j.ypmed.2009.06.025

Quinlan, M. (2007). Organisational restructuring/downsizing, OHS regulation and worker health and wellbeing. International Journal of Law and Psychiatry, 30(4-5), 385-399.

http://dx.doi.org/10.1016/j.ijlp.2007.06.010

Raediker, B., Janssen, D., Schomann, C., \& Nachreiner, F. (2006). Extended working hours and health. Chronobiology International, 23(6), 1305-1316. http://dx.doi.org/10.1080/07420520601096245 
Robbins, S. B., Allen, J., Casillas, A., Peterson, C. H., \& Le, H. (2006). Unraveling the differential effects of motivational and skills, social, and self-management measures from traditional predictors of college outcomes. Journal of Educational Psychology, 98(3), 598-616. http://dx.doi.org/10.1037/0022$\underline{0663.98 .3 .598}$

Rodriguez-Sanchez, A., Schaufeli, W., Salanova, M., Cifre, E., \& Sonnenschein, M. (2011). Enjoyment and absorption: An electronic diary study on daily flow patterns. Work \& Stress, 25(1), 75-92. http://dx.doi.org/10.1080/02678373.2011.565619

Ryff, C. D., \& Keyes, C. L. (1995). The structure of psychological well-being revisited. Journal of Personality and Social Psychology, 69(4), 719-727. http://dx.doi.org/10.1037/0022-3514.69.4.719

Salanova, M., Bakker, A. B., \& Llorens, S. (2006). Flow at work: Evidence for an upward spiral of personal and organizational resources. Journal of Happiness Studies, 7(1), 1-22. http://dx.doi.org/10.1007/s10902$\underline{005-8854-8}$

Schaufeli, W. B., Salanova, M., Gonzales-Roma, V., \& Bakker, A. (2002). The measurement of engagement and burnout: A two sample confirmatory factor analytic approach. Journal of Happiness Studies, 3(1), 71-92. http://dx.doi.org/10.1023/A:1015630930326

Schmutte, P. S., \& Ryff, C. D. (1997). Personality and well-being: Reexamining methods and meanings. Journal of Personality and Social Psychology, 73(3), 549-559. http://dx.doi.org/10.1037/0022-3514.73.3.549

Seligman, M. E. P., \& Csikszentmihailyi, M. (2000). Positive psychology: An introduction. American Psychologist, 55(1), 5-14. http://dx.doi.org/10.1037/0003-066X.55.1.5

Skakon, J., Nielsen, K., Borg, V., \& Guzman, J. (2010). Are leaders' well-being, behaviours and style associated with the affective well-being of their employees? A systematic review of three decades of research. Work \& Stress, 24(2), 107-139. http://dx.doi.org/10.1080/02678373.2010.495262

Sparks, K., Faragher, B., \& Cooper, C. L. (2001). Well-being and occupational health in the 21st century workplace. Journal of Occupational and Organizational Psychology, 74(4), 489-509. http://dx.doi.org/10.1348/096317901167497

Vasilopoulos, N. L., Cucina, J. M., Dyomina, N. V., Morewitz, C. L., \& Reilly, R. R. (2006). Forced-choice personality tests: A measure of personality and cognitive ability? Human Performance, 19(3), 175-199. http://dx.doi.org/10.1207/s15327043hup1903 1

Vasilopoulos, N. L., Cucina, J. M., \& Hunter, A. E. (2007). Personality and training proficiency: Issues of bandwidth-fidelity and curvilinearity. Journal of Occupational and Organizational Psychology, 80(1), 109-131. http://dx.doi.org/10.1348/096317906X102114

Warr, P. (1987a). Work, unemployment, and mental health. Oxford: Clarendon Press.

Warr, P. (1987b). Job characteristics and mental health. In P. Warr (ed.), Psychology at work (pp. 247-269). Harmondsworth: Penguin Books.

Welbourne, J. L., Gangadharan, A., \& Sariol, A. M. (2014). Ethnicity and cultural values as predictors of the occurrence and impact of experienced workplace incivility. Journal of Occupational Health Psychology, 20(2), 205-217. http://dx.doi.org/10.1037/a0038277

Wengraf, T. (2001). Qualitative research interviewing. Sage. Great Britain: Cromwell Press. http://dx.doi.org/10.4135/9781849209717

Yin, R. K. (2003). Case study research: Design and methods, 3rd Edition. London: Sage.

Zellars, K. L., Perrewe, P. L., \& Hochwarter, W. A. (2000). Burnout in health care: The role of five factors of personality. Journal of Applied Social Psychology, 30(8), 1570-1598. http://dx.doi.org/10.1111/j.1559$\underline{1816.2000 . t b 02456 . x}$ 